\title{
AS POLÍTICAS DOS CABELOS NEGROS, ENTRE MULHERES: ESTÉTICA, RELACIONALIDADE E DISSIDÊNCIA NO RIO DE JANEIRO
}

\author{
Mylene Mizrahi ${ }^{1}$
}

${ }^{1}$ Pontifícia Universidade Católica do Rio de Janeiro, RJ, Brasil

Arte, defendeu Alfred Gell (1998) de modo inédito e definitivo em Art and agency, livro que completa 20 anos de sua primeira publicação, não diz respeito ao belo, ao agradável, mas é definida por suas capacidades transformativas, provocativas, por suas potências de captura. Esse novo entendimento, que revolucionou não apenas a antropologia da arte, mas também contribuiu para desestabilizar o campo mais amplo da reflexão em torno da arte, colaborou ainda para, ao mesmo tempo, criticar a "atitude estética" na própria raiz da definição de estética ocidental. Tal atitude presidia as distintas abordagens dos objetos de arte, inclusive as antropológicas, e se erigiu, de um lado, sobre uma noção de belo universal e, de outro, sobre o abandono do laço entre forma e função. Ao advogar pela rearticulação entre ética e estética, forma e função, desconsiderada pelas abordagens anteriores, Gell buscava caminhos para escapar de uma provável estetização.

O problema, podemos depreender de suas proposições, residia não no fato de fazermos da estética entrada privilegiada para as nossas análises em torno das formas expressivas, mas em uma atitude incapaz de desvincular a abordagem estética de sua correlação com o belo e o bom, conceituados universalmente e em geral de modo coincidente com a perspectiva do pesquisador. Como o autor deixa mais evidente em seu artigo sobre a tecnologia do encantamento, os objetos artísticos devem interessar ao antropólogo não por agradar aos seus gostos ou sentidos, mas pelas "consequências sociais" que sua produção, circulação e consumo geram (Gell 1992).

Gell estava assim reivindicando que renunciássemos ao olhar enviesado que vinha presidindo as análises antropológicas sobre as formas expressivas não ocidentais, renúncia esta inerente ao seu projeto de reconceituação da arte e da estética. Mas a despeito dos efeitos que Gell e seu livro causaram, seguimos sendo surpreendidos por pesquisas que acionam recorrentemente a 
noção de estética para ora recortar mundos culturais, ora acessar o que pode haver de belo ou de agradável na vida social. No primeiro caso, a estética é coisificada, como podemos entrever em falas do tipo "deixe-me ver como é a estética desse povo" ou em formulações que descrevem a estética de uma determinada manifestação cultural. Nesse caso, o termo parece estar sendo empregado como sinônimo de estilo ou como meio de reificação da cultura. No segundo caso, em que a estética se refere ao agradável e ao prazeroso, um fenômeno ou manifestação pode ser entendido como tão estético que, diriam, não poderia ter qualquer dimensão política. Ou, ao contrário, um fenômeno tido como desagradável, que nos cause nojo, por exemplo, não poderia jamais ser abordado de um ponto de vista estético ou apreciado esteticamente.

O ponto, contudo, não parece residir em agradar aos sentidos ou permitir recortar uma forma cultural. Estética diz respeito à ação e resulta sempre em uma discursividade política, como podemos depreender das formulações de Jacques Rancière a respeito de uma partilha do comum (Rancière 2005). Vivemos, defende o autor, em um "regime estético" no qual tomar parte no comum refere-se não apenas ao que é partilhado, mas igualmente ao que é segregado. A estética diz respeito assim a quem pode se deixar ver, a quem pode fazer parte desse comum e que possui as habilidades que lhe permitem participar desse comum: aqueles que falam e se fazem ver e ouvir. Participar nessa estética do comum envolve, portanto, uma necessária produção de sujeitos políticos que se colocam em uma disputa permanente. Mostrar, fazer ouvir, fazer ver e fazer falar dependem, sempre, de uma disputa que força os limites daqueles que poderão ser vistos e escutados, impondo-se por meio dessa mesma disputa.

Neste artigo, parto dessas inquietações, que me fornecem também enquadres analíticos, para considerar a possibilidade de falarmos em "estéticas negras", perguntando em que, afinal, residiria sua particularidade, sua singularidade, para que as nomeássemos de tal modo. O caminho parece ser o de tomar a estética não tanto para reduzi-la à forma e à aparência, sem, contudo, excluí-las da análise, mas para concebê-la como uma força, uma potência. Como algo que produz efeitos sobre o mundo, como proposto por Rancière e também por Gell. Uma concepção de estética, portanto, muito distinta da que autonomizou a apreciação da forma de uma ética e se fundou sobre a noção de belo universal.

A noção de belo já estava em xeque desde "os debates de Manchester" (Ingold 1994) que, em uma de suas edições, propôs uma moção em torno da validade do uso transcultural do termo estética, produzindo como desdobramento o questionamento sobre se seria o belo eficaz para conceituarmos 
a arte e distinguirmos objetos artísticos em diferentes sociedades. De um lado do debate, se posicionaram os antropólogos que expressaram uma concepção universalista da percepção estética ao defenderem que todos os povos distinguiriam alguma classe de objetos como belos e artísticos. Do outro, estavam os antropólogos opositores ao uso do termo em contextos etnográficos, ao entenderem que o mesmo carregaria a própria definição ocidental de arte, envolvendo, portanto, o julgamento de uma cultura em termos de sua capacidade de produzir o belo e impedindo o estudo de objetos e imagens que contrariassem tais pressupostos, fundados, em última instância, sobre nossos próprios gostos.

O grupo contrário à moção venceu o debate, e a estética, apreendida como fenômeno do Modernismo europeu, saiu vencida sob o argumento de que seria coextensiva ao julgamento da beleza e do gosto. Em um certo sentido, considerou-se que o vencedor do debate foi mesmo Pierre Bourdieu, cujo argumento montado para desmontar a estética kantiana foi acionado na defesa do abandono dos usos transculturais para o termo estética. Bourdieu demonstrou, em A Distinção, que não haveria nada como um gosto "puro" e desinteressado, como defendeu Kant em sua crítica do julgamento estético, concernente à apreciação dos objetos de arte, mas que os gostos estavam fundados sobre os diferentes habitus de classe. Todo gosto seria assim um desgosto; envolveria sempre o julgamento do gosto alheio (Bourdieu 1984).

A despeito das armadilhas que os usos do termo estética podem colocar, o que parece potente não é abandoná-lo, mas voltar a seu significado primeiro, primordial que, como demonstrou Susan Buck-Morss (2012), tem menos a ver com a arte, como a conhecemos no Ocidente, e mais com um vivenciar dos sentidos, um vivenciar feito fundamentalmente pelo corpo. Pensar em uma politização da estética torna-se possível assim, a partir de um corpo que conhece através dos sentidos, em contraposição a uma estetização da política, na qual a estética resultaria de uma anestesia à recepção dos estímulos externos que o mundo traz. Significa, portanto, escapar de uma anestética, uma estética como prazer desinteressado, esvaziado de sentido ético, de compromisso com aquela realidade mesma que descrevemos, atitude presente na própria raiz da noção de estetização.

Buck-Morss faz essas formulações a partir de sua leitura do ensaio seminal de Walter Benjamin sobre a arte em tempos de sua reprodutibilidade técnica (Bejnamin 2012). O que move a autora é particularmente o trecho final do ensaio de Benjamin, no qual o autor afirma que o fascismo opera por meio de uma estetização da política. As grandes paradas e manifestações próprias aos nacionalismos europeus seriam assim a expressão de um regime que permite às massas se manifestarem ao mesmo tempo em que 
faz da política campo inócuo de ação: "O fascismo vê sua salvação não em fazer valer o direito das massas, mas em permitir que elas se manifestem" (Benjamin 2012:32). A saída para essa "estetização da política" seria, propõe Benjamin, "politizar a arte". Como consequência de tal inversão, argumenta Buck-Morss, "a arte deixaria de ser arte tal como a conhecemos" e o termo estética passaria a descrever o próprio "campo em que o antídoto do fascismo se manifesta como resposta política". Ao propor politizar a arte, Benjamin teria possibilitado à arte e à estética adquirirem estatutos outros, exigindo da arte a tarefa de "desfazer a alienação do sensório corporal", permitindo um retorno ao que seria o "campo original da estética": "a natureza material, corpórea" (Buck-Morss 2012:155-157).

É sobre o entendimento que Buck-Morss faz da estética como uma forma de cognição produzida por meio do corpo, operada através de nosso aparelho sensório-corporal junto à matéria do mundo (Buck-Morss 2012:158), que gostaria de seguir perguntando em que medida podemos falar de uma estética negra, pensando-a a partir dos desafios múltiplos colocados pelo espaço social e a ele recolocados pelos corpos que por esse mesmo espaço social se fazem passar. Faço isso junto à crescente estilização da vida coletiva que tem acompanhado o vivenciar da cidade. Ocupar a cidade tem se dado primordialmente por meio das artes urbanas e outras manifestações estéticas e estilísticas. Interessam-me, em particular, os deslocamentos de jovens pelo espaço urbano e o modo como convertem suas estéticas corporais em discursividades políticas, produzidas pela materialidade do corpo e junto às coisas acessadas como bens de consumo.

Mais especificamente, detenho-me nas estratégias de autoapresentação negras, com foco nos cabelos, para acompanhar o modo pelo qual as articulações entre classe, raça, gênero e também geração não apenas pautam as interações sociais, mas também agem sobre a produção das aparências dos sujeitos e seus corpos em fluxo pelo espaço público. Junto aos cabelos, exploro as injunções entre estética, política e criatividade, notando como o self produz a si ao produzir o seu corpo e, nesse processo, altera a paisagem da cidade.

Argumentarei que falar em estéticas negras e sua distintividade torna-se possível por duas vias. De um lado, temos a sua qualidade dissidente, na medida em que se fazem negras por contraste e/ou recusa ao gosto hegemônico, que é também branco. Esse contraste-e-recusa pode ser acessado ora a partir de uma diferença radical, ora a partir de uma diferença que se faz na busca por uma similitude mais ou menos enfatizada. Essa qualidade dissidente contém também a sua qualidade relacional, que evidencia como a estética negra, seja em sua produção, seja em seu efeito, coloca em questão 
a relação com um branco. Essa relacionalidade é apreendida justamente quando são considerados os deslocamentos pela cidade, de modo que a estética corporal é produzida e acionada visando potencializar a circulação dos sujeitos pelo espaço urbano. Tal potencialização pode ser feita tanto por meio de uma certa invisibilidade quanto por meio da explicitação e, como consequência, do conflito e do desafio.

Elaborarei em torno de três estilos de cabelos femininos que são, cada um a seu modo, respostas esteticamente motivadas aos racismos cotidianos com os quais os sujeitos negros são obrigados a se deparar em suas interações urbanas. Esses estilos compõem performances realizadas em desafio aos estereótipos com os quais esses sujeitos são julgados, classificados e observados pelo olhar racializador, branco ou não negro. As formulações de Mara Viveros Vigoya (2018) e de Michelle Ann Stephens (2014) sobre o tema são centrais, e passo a elas

Stephens, ao elaborar sobre artistas negros norte-americanos, argumenta que a fonte do fascínio que suas performances exercem sobre suas audiências deriva da sensação "que permanece nos olhos" do observador muito tempo depois de sua fonte desaparecer. Esse fascínio deriva de uma imagem que tem por sede sua pele muito mais do que sua carne, separação que, argumenta Stephens, é a própria expressão da operação de racialização do outro negro, tipicamente moderna, fundada sobre duas maneiras de conhecer a negritude e de interagir com ela. Em um aspecto, temos a "identidade racial" como resultante de um "olhar epidermalizador" que perscruta o corpo a partir de sua superfície. Mas em outro, temos a performance como representação de "uma experiência do corpo negro sentido como carne permeável", relacionável (Stephens 2014:10). Viveros Vigoya localiza nesta tensão entre pele e carne o meio através do qual homens negros se tornam sujeitos junto a um corpo que interpela o olhar branco que os aliena. É da possibilidade de considerar a carne que emerge uma "subjetividade negra encarnada, cujas relações com a negritude diferem das que refletem o olhar dos que buscam fixá-la em um estereótipo" (Viveros Vigoya 2018:124).

É a par com esse tensionamento que, penso, o sujeito negro devolve ao observador perscrutador e ao espaço social suas respostas. Respostas estéticas, engendradas criativa e politicamente. Stephens e Viveros Vigoya me permitem, portanto, levar adiante o ponto que busco fazer com Buck-Morss: o de que a estética é produto de uma cognição exercida pelo corpo. De um certo modo, atualizo a problemática que venho perseguindo junto às performances de Mr. Catra, artista de funk carioca falecido em setembro de 2018, e que adensei em artigo recente (Mizrahi 2018b). Cada um dos estilos que diferenciarei ao longo deste artigo se refere a modos diferenciais 
de o corpo sentir, conhecer e responder política e criativamente às imagens cristalizadas e racializadas produzidas sobre a negritude. Suscitam, ainda, diferentes aportes conceituais que, se me são ensinados e serão formulados em proximidade com um estilo específico, permitem acessar o sentido dos outros.

Na primeira seção do artigo discorro sobre o processo de colocar e retirar extensões de cabelos naturais, humanos, por mulheres ligadas ao funk carioca, universo no qual empreendi minha formação e trajetória de pesquisa acadêmicas. ${ }^{1}$ Os cabelos ambíguos, aos quais desse modo nomeio em alusão à fluidez buscada pela pessoa feminina funk, elidem sua condição de feito e fazem, da ambiguidade racial, agência. Permitem ainda elicitar a especificidade da relacionalidade da pessoa feminina funk, noção que exploro na segunda seção do artigo. Na terceira seção, a partir do diálogo com diferentes autores, adenso o que pretendo formular com a noção de estética relacional dissidente. Na quarta seção, detenho-me sobre os cabelos Black e os turbantes afro, que me colocam a possibilidade de considerarmos a raça em sua dimensão performativa. Estabeleço uma discussão sobre as tensões entre naturalidade e artefatualidade colocadas pela beleza corporal e sobre apropriação cultural. Por fim, antes de passar às conclusões, volto-me para as extensões pop - cabelos feitos por fibra sintética e evidentemente não humanos - para expandir a noção de corpo artefatual, explorada em outra ocasião (Mizrahi 2018a), e propor que é da possibilidade de fazermos dos bens de consumo tecnologias do self que as estéticas corporais podem ser produzidas com vias a se tornarem discursividades políticas.

Ao me debruçar sobre essa confluência estilística, quero acompanhar os agenciamentos da pessoa via aparência, agenciamentos que permitem acessar o papel que as relações de classe, gênero, raça e geração desempenham no espaço urbano brasileiro, particularmente o carioca. Em continuidade com a abordagem que venho empreendendo, tomarei os bens de consumo e outras intervenções estéticas, cujo acesso é mediado pelo mercado, como coisas que nos permitem adentrar mundos conceituais particulares (Holbraad 2007). Tomá-los-ei igualmente como próteses, como "coisas que são da pessoa e mais que a pessoa" (Strathern 2004:76): coisas que não apenas ampliam as capacidades da pessoa, mas também lhe concedem capacidades outras. Evidencio, assim, a dimensão protética da aparência, observando os processos criativos que a pessoa engendra para produzir a si. 


\section{Os cabelos ambíguos}

O primeiro estilo de cabelos distingo no funk carioca. O universo de relações que o funk carioca traça é mais propriamente reconhecido pelo caráter inequívoco de sua estética corporal, erigida segundo uma lógica da sedução que opõe, de modos simultaneamente lúdicos e agonísticos, os sexos. Mas é o caráter ambíguo da aparência feminina que me interessa explorar aqui, caráter tornado potente quando se coloca em questão não as relações entre os gêneros feminino e masculino, mas a circulação pelos espaços da cidade. A aposta dessas mulheres reside na ambiguidade da aparência corporal. Reside na busca por uma aparência não branca, que simultaneamente diferenciam do que é entendido como uma estética negra tradicional que, por sua vez, é delineada fundamentalmente a partir dos cabelos afro. Já o estilo de cabelos que produzem, e que denominei como cabelos ambíguos, é feito por cabelos humanos, que podem ser delas próprias ou elaborados por meio de extensões de cabelos não inatos, mas também humanos. A ambiguidade da aparência corporal é habilmente explorada por essas jovens mulheres que, ao mesmo tempo em que buscam visibilidade, o fazem através de uma certa invisibilidade. De um certo modo remetem à problemática descrita por Sander Gilman (1999) a respeito das distintas maneiras com que os judeus alemães e os negros norte-americanos encontraram para lidar com o racismo. 
Ao traçar a história da beleza corporal no Ocidente, Gilman (1999) contrapõe os esquemas corporais do judeu e do negro em seus espaços de circulação, mostrando como o nariz foi elemento que reuniu ambos os grupos étnicos em uma mesma categoria de perigo social. Mas se em fins do século XIX um homem judeu na Alemanha poderia entrar em ambientes brancos contanto que não parecesse "judeu demais", conjuntura que favoreceu o desenvolvimento da moderna rinoplastia, nos Estados Unidos um regime formal de segregação racial impedia a entrada e a circulação de negros em ambientes sociais brancos. Os judeus berlinenses, ao apagarem marcas étnicas por meio de cirurgias plásticas que alteravam a forma de seus narizes, buscavam adquirir "visibilidade por meio da invisibilidade". Já nos Estados Unidos, o ponto não era se tornar invisível, mas evitar ser "excessivamente visível". É nesse contexto que a cosmetologista Madame C. J. Walker, com seus produtos para alisar os cabelos ou clarear a pele, inaugura, no início do século XX, a entrada de afro-americanos no clube dos milionários norte-americanos (Gilman 1999:85-137). ${ }^{2}$

No que diz respeito ao funk carioca, por meio de um estilo de cabelos que é não branco, como reiteraram minhas interlocutoras, produz-se uma pessoa negra que busca escapar tanto de uma representação de negritude mais propriamente brasileira - resultante da sobreposição entre raça e classe que localizam nos cabelos alisados - ou de representações de negritude tradicional, como a produzida por meio dos cabelos afros. Com seus penteados e extensões, produzem cabelos que não são lisos como os das mulheres brancas, nem crespos como os Black, e assim potencializam a sua circulação pela cidade, driblando o racismo e os preconceitos de raça de modo silencioso e fazendo da ambiguidade racial agência. ${ }^{3}$

Mas é no momento de sua produção que os cabelos ambíguos trazem à tona aspectos que permanecem invisibilizados em seu resultado final. Especificamente, é no processo de colocar e retirar extensões de cabelos que notamos seu caráter artefatual, a ideia de beleza feita que o acompanha, bem como o modo como sua feitura é pautada pelas relações entre brancas e negras. É a artefatualidade desses cabelos que permite entrever como uma relação não harmoniosa com a mulher branca norteia a produção da pessoa feminina funk.

Com frequência, era para Madureira que nos dirigíamos quando o assunto era a beleza corporal. Bairro icônico da Zona Oeste do Rio de Janeiro, Madureira abriga as escolas de samba Portela e Império Serrano, é reduto de bicheiros e do comércio em torno da umbanda e se constitui em grande centro de compras, particularmente no que se refere à moda de vestuário, à produção de cabelos e penteados, bem como outros itens relativos à autoapresentação. Visitá-lo foi sempre motivo de alegria. 
Em uma tarde, estávamos reunidas na sala privada de um salão de cabelereiros. A cabelereira Renata retirava as extensões da cabeça de uma de minhas amigas, que chamarei de Tábata, que queria ter a raiz de seus cabelos "relaxada": tornada mais "baixinha" por meio da aplicação de produto químico. Queria ainda permitir a seus cabelos "respirar", "descansar" sem as extensões, para, dali a alguns meses, recolocá-las. Enquanto cortava com uma tesourinha o fino elástico que prendia as extensões às mechas originais, Renata me perguntava "de onde surgiu" a ideia para o meu estudo, o que explico refazendo abreviadamente a minha trajetória de pesquisa. Tábata disse então: "parece que ela tá vendo um outro mundo". Respondi que ela estava certa, que até então eu, sendo branca, pouco sabia sobre as extensões capilares. E Renata, parecendo concordar, disse que de fato "o modo de uma negra se arrumar é totalmente diferente do de uma branca".

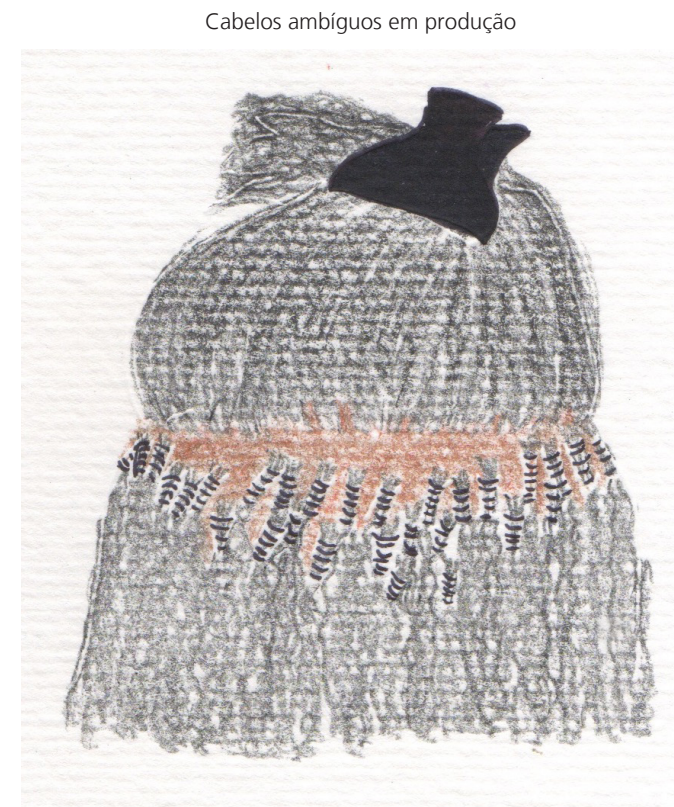

Renata fez a ponte fundamental: investigar a produção de seus cabelos significava investigar também modos não brancos de produzir a beleza. Modos que relacionavam não apenas questões de gosto ou apenas aspectos relativos à materialidade, mas que também colocavam em foco o que lhes parecia ser uma essência do corpo negro e era trazido à luz por contraste com uma essência branca. Desse modo, elas eram como que "montadas", termo que se utiliza para o processo de preparação de travestis, ali um montar que 
envolvia "sofrimento": nós, as brancas, não teríamos a "resistência" delas e não imaginaríamos o quanto "sofriam para ficar bonitas". Célia, parente de Tábata, acrescentou que "até o modo de colocar implante de vocês é mais simples", já que, segundo ela, os fios das extensões são colados com pistola de "cola quente". Depois, continua Célia, basta lavar a cabeça para que o excesso de cola saia e possa se passar o pente "normalmente, como se fosse o seu cabelo".

Se a aparência se mostrava fundante para a produção da pessoa feminina funk, o cabelo adquiriu de fato lugar privilegiado nesse processo. Era para os cabelos que qualquer entrada extra de dinheiro era invariavelmente destinada. Nesses anos todos de relação com essas mulheres, em duas ocasiões apenas me pediram dinheiro: uma vez para colocar cabelos, outra vez em caso de doença grave.

\section{A relacionalidade da pessoa feminina funk}

Em outra ocasião, sugeri que a relacionalidade da pessoa masculina funk constituía-se a partir de suas relações com múltiplas mulheres. Nessa conjuntura, os bens de riqueza denotam simultaneamente poder financeiro e potência sexual, compondo uma aparência que revela poderes internos da pessoa, que de outra maneira ficariam invisibilizados. Como resultado, as mulheres, em vez de surgirem objetificadas, como muitas vezes costuma-se pensá-las, revelam, outrossim, as potências de um homem que só se faz poderoso junto a elas. É o homem, nesse caso, quem surge reificado no momento da performance (Mizrahi 2018a).

O feminino, que acompanhei ser produzido por meio da beleza, se fazia independente do mundo masculino e não com vistas à sedução. As muitas conversas estabelecidas com e entre minhas amigas em campo jamais giraram em torno dos homens ou de uma potencial conquista. $\mathrm{Na}$ verdade, o homem não era nem mesmo um tema. Era, outrossim, como um apêndice: o motorista, o segurança, o secretário. Além disso, as conversas entabuladas no momento de produção de seus cabelos tematizavam essencialmente a importância que o estar bela tinha para elas se situarem no mundo. Como diziam, sem o cabelo arrumado, tratado, não saíam nem de casa. Uma configuração muito diferente da que pude notar ao acompanhar os homens, que reiteradamente presentificavam a mulher, o que era feito essencialmente por meio de falas sobre a sexualidade, o pênis e a vagina e as conquistas amorosas. 
A relacionalidade da mulher é definida não pela relação com a sua contraparte masculina, e sim na relação com sua contraparte feminina branca, algo que emerge mais claramente na intimidade do montar e desmontar de cabelos. Os cabelos ambíguos revelam a vontade de subsumir a mulher branca, ao mesmo tempo em que mostram que essa subsunção não se faz em função de um desprezo absoluto, mas é também movida pelo reconhecimento dos poderes que o branco tem e que interessam ser incorporados, como mostrou outra situação em Madureira.

Estávamos em uma loja com paredes recobertas por expositores de cabelos humanos. Em um desses suportes estavam expostos cabelos pretos. Em outro, víamos cabelos louros, vermelhos, castanhos e também pretos. Célia se dirigiu aos cabelos louros, atraída por eles. Tocou-os e disse que, quando comprasse os seus, seriam "daquele tipo, macios". Mas os tingiria de preto. Primeiro o aspecto de louro atraiu Célia, para depois averiguar que se tratava de cabelos macios. Se a maciez interessou à Célia, o que a atraiu para aqueles cabelos especificamente foi sua aparência de louro. O que a capturou parece ter sido a possibilidade de realizar a operação de englobamento da beleza branca - contida tanto na maciez quanto na coloração do amarrado de cabelo - pelo corpo negro. Não à toa Célia afirmou, em ato contínuo ao toque, que os tingiria de preto. A graça parecia residir em tornar um cabelo louro em preto, com a maciez denunciando não apenas a sua condição original, mas a própria operação de englobamento. 
Célia sabia que expressava um ideal, e o fazia por meio de um exercício imaginativo, como denuncia o seu "no dia em que eu comprar". Comprar e colocar cabelos suficientes para alongar os seus próprios fios lhe custariam algo como dois e meio salários mínimos, valor que ela e muitas outras mulheres desse universo não possuíam, o que colocava em ação uma cadeia de doadores e tomadores de cabelos. Juntas, exploramos diferenças nos modos de vestir, modos que evidentemente me delinearam como modelo. Diziam que, caso eu vestisse a mesma roupa que elas, o resultado não seria o mesmo. A diferença, contudo, não estava no corpo, já que cada uma delas tinha um tipo físico. A diferença estava no "jeito". Tampouco usariam as mesmas roupas que eu, o que afirmaram notando que raramente eu deixava minhas pernas à mostra. A justificativa que dei para tal - o fato de não me sentir à vontade vestindo "sainha" nas muitas tardes passadas no estúdio de gravação, um ambiente eminentemente masculino - lhes pareceu uma bobagem.

\section{Estéticas negras dissidentes}

Edmund Leach (1983), em ensaio seminal sobre os aspectos pragmáticos do símbolo, nos mostra como os cabelos e seus distintos significados atravessam culturas, e argumenta que sua potência reside em sua "magia", em seu poder de alterar o estado das coisas. O poder dos cabelos está diretamente relacionado ao seu caráter público e social. Desse modo, importam não os cabelos e os pelos, mas aqueles "socialmente visíveis". De minha parte, os cabelos interessam não tanto por seu simbolismo genérico ou generalizável, mas sobretudo por seus poderes de alterar as situações em um sentido mais "emocional", como formulou Leach. São os cabelos que me permitem desvendar o que pode haver de distintivamente negro em estéticas adjetivadas como tais.

Mas sou obrigada a discordar de Leach quando ele afirma que não é relevante entender o motivo que levou determinados elementos materiais a adquirirem significados simbólicos particulares. ${ }^{4}$ No meu entender, conflitos, pontes, conexões, provocações e paixões que os cabelos produzem não poderiam ser causados por qualquer outro significante. Cabe assim destacar alguns aspectos que concedem particularidade aos cabelos e que derivam de seu aspecto material.

Em primeiro lugar, destacaria sua plasticidade e resiliência. O cabelo, matéria viva, é também matéria morta. Pode ser torcido, tingido, moldado em metal incandescente, alterado por meio de tratamentos químicos sem que, 
contudo, qualquer dessas operações cause dor ou seja irreversível. Outro aspecto de grande relevância para acessarmos a potencialidade dos cabelos reside em ser "socialmente visível", como destacou Leach, qualidade esta diretamente relacionada ao lugar que a cabeça adquire na ornamentação da pessoa, nas elaborações de beleza e no poder de sedução exercido sobre o outro social. Um certo poder universal que podemos atingir junto ao fascínio extemporâneo e transcultural que o mito da Medusa e suas representações visuais seguem causando (Garber \& Vickers 2003).

Mas, por outro lado, e aqui distingo um terceiro traço, se os cabelos têm um apelo estético universal, o lugar distintivo que eles ocupam em culturas negras não deve ser subestimado. Um lugar que, mais uma vez, está diretamente ligado ao seu componente social, o que pode ser aferido pelo papel que ele desempenha em manifestações tradicionais africanas (Lody 2004; Eglash 2005; Tarlo 2016), e ainda em estilos contemporâneos, o que é atestado por sua presença ubíqua em comunidades negras formadas em contextos multiculturais. Bairros negros são invariavelmente tomados por cabelos, em lojas, em salões de cabelereiro ou descartados pelas calçadas. Um cenário que não se repete, por exemplo, em comunidades latinas, árabes ou muçulmanas.

Como argumenta Kobena Mercer, o cabelo negro fornece uma série de "soluções estéticas" para o amplo espectro de problemas criados pelas ideologias da raça e do racismo, e é graças à sua capacidade de responder estilisticamente à panóplia de forças históricas que ele se tornou não apenas carregado de significado simbólico e social, mas também político (Mercer 2000:115-112). Gomes igualmente defende a dimensão incondicionalmente política do cabelo negro, argumentando que, "mesmo apresentando-se alisado, pranchado ou alongado", o cabelo "sempre será crespo e sempre remeterá à raça negra" (Gomes 2006:144). É desta perspectiva que defendo que os cabelos adquirem lugar privilegiado na produção da pessoa negra, argumentando que as estéticas corporais negras são eminentemente relacionais, traço que se articula à sua qualidade de dissidente. Refino o que pretendo com a noção de estética relacional dissidente.

Poder-se-ia contra-argumentar que as estéticas corporais têm sempre uma dimensão relacional, na medida em que elas carregam consigo, inevitavelmente, um elemento de comunicação. Como propõe Marshall Sahlins (2003), em uma sociedade de estranhos é por meio da aparência que reconhecemos e classificamos uns aos outros. Contudo, a especificidade do modo como as estéticas brancas e negras se comunicam reside não em sua mutualidade, mas no caráter assimétrico dessa mesma mutualidade, caráter este que pode ser acessado pela hegemonia das primeiras em face das segundas. 
Este aspecto foi formulado de modo claro por James Baldwin que, em meio à narrativa pessoal de sua vivência em um vilarejo suíço onde jamais um negro havia colocado os pés antes, nos mostra que

há uma grande diferença entre ser o primeiro homem branco visto por africanos e ser o primeiro homem negro visto pelos brancos. O homem branco considera esse espanto um tributo (...) enquanto eu, sem planos de conquista, encontro-me em meio a pessoas cuja cultura me controla (...).

Essas pessoas não poderiam ser, do ponto de vista do poder, estranhas em nenhum lugar do mundo; na verdade, elas fizeram o mundo moderno, mesmo que não saibam disso. O mais iletrado deles é próximo, de uma maneira que eu não sou, de Dante, Shakespeare, Michelangelo, Ésquilo, da Vinci, Rembrandt e Racine; a catedral de Chartres lhes diz alguma coisa que não diz a mim (...). De seus hinos e danças, saíram Beethoven e Bach. Volte alguns séculos e ele estão em plena glória - mas eu estou na África, assistindo à chegada dos conquistadores (Baldwin 2017:119).

É também esta condição de se ver como um estranho em meio a brancos que Henri Louis Gates Jr. (1994) traduz em seu belo ensaio "In the kitchen". Na cozinha de sua casa, espaço diminuto, preparam-se alimentos, banham-se corpos e moldam-se cabelos. É em meio a esses odores, sabores e calores que o menino Henry acompanha os dramas de sua mãe e dos amigos negros desta, cujos cabelos são alisados pelo pente de metal tornado brasa, após repousar por um mínimo de trinta minutos sobre a chama do fogão. Cabelos que eram sempre "cozidos", fossem eles relaxados ou cacheados, tendo por referência o cabelo liso do homem branco. Ainda que "liso" significasse para os negros apenas "não crespo", como nota o autor.

A ideia de estética relacional foi explorada por diferentes autores, tendo como cerne as conexões estabelecidas entre os sujeitos envolvidos nos processos de interação social. Marilyn Strathern (2013), em Learning to see in Melanesia, argumenta que, no contexto ritual melanésio, a estética refere-se à forma adequada pela qual o doador consegue capturar a atenção do receptor da troca. Desta perspectiva, o doador constitui o parceiro da troca e nesse processo torna visíveis, por meio dos artefatos que recobrem a superfície de seu corpo, as relações que o compõem. Pessoa e relações se tornam explicitamente visíveis e é no momento da performance e da troca cerimonial que a forma corporal revela as potencialidades internas das quais a pessoa é feita. A pessoa, no contexto ritual, é como se fosse virada pelo avesso. 
Elsje Lagrou (2018) argumenta a favor de uma "estética relacional ameríndia" tendo por ponto de partida o universo de transformabilidade que resulta nas imagens-canções produzidas no contexto ritual xamânico huni kuin. Os cantos apontam para as articulações entre visão, ritmo, canto e som, para as conexões entre os seres viventes e seus sucessivos processos de transformação, e ainda para uma pessoalidade fractal, segundo a qual a pessoa que canta é sempre composta por duas almas, uma que tem as percepções e outra que procede à interpretação. Por fim, vale notar ainda a contribuição ao debate por Nicolas Bourriaud (2002), curador e crítico de arte, aquele que talvez tenha sido o principal responsável pela disseminação da ideia de estética relacional no campo da arte contemporânea. O autor argumenta que, no cenário atual, o significado do objeto de arte não reside nele mesmo, mas nas trocas e nas doações que ele possibilita e articula. Em uma palavra, em sua capacidade de produzir relação, uma qualidade que não é estranha às análises antropológicas.

Expandindo a formulação de Strathern em Learning to see in Melanesia e retomando a noção de conectividade - com a qual exploro as "conexões parciais" (Strathern 2004) que o sujeito funk estabelece para garantir sua recepção nos mais distintos espaços sociais sem abrir mão de sua singularidade estilística, artística e política - quero argumentar que a relacionalidade das estéticas negras está diretamente articulada à sua qualidade dissidente, a uma vontade de desvio da norma que, contudo, não deixa de levar em conta essa mesma norma, o gosto branco hegemônico. Vimos como os cabelos ambíguos se fazem a partir de uma recusa múltipla: de uma identidade negra tradicional; do lugar estabelecido para o negro na estrutura social brasileira, identificado a partir da sobreposição entre raça e classe; recusa também de cabelos "brancos". Nas próximas seções qualificarei de que maneira essa tensão entre norma e dissidência opera na produção de outros dois estilos de cabelos negros.

\section{Os turbantes e os cabelos Black}

Se os cabelos ambíguos apostam em um estilo que silenciosamente lida com o racismo e os preconceitos de classe, há cabelos que encerram modos mais explícitos de lidar com essas mesmas clivagens. Cabelos que produzem um estilo explicitamente não branco e que não se preocupam em evitar conflitos. Ao contrário, afirmam uma pertença identitária por meio de uma estética que radicaliza a diferença junto à forma e à beleza. Cabelos cujas donas almejam desestabilizar, através da aparência e do gosto, a paisagem estabelecida da cidade, impactando-a visualmente. 
É, portanto, por contraste com um modo mais ambíguo de produzir a beleza e de lidar com os preconceitos de raça e classe que abordo tanto os cabelos Black como os turbantes afro. Pois, se no caso dos cabelos ambíguos, o que se quer é potencializar a circulação pelos espaços sociais, ganhando visibilidade por meio da invisibilidade - exibir-se, de um certo modo, atenuar as marcas étnicas sem no entanto - e este ponto é de suma importância buscar tornar-se o outro branco - no caso dos cabelos Black, e mais ainda dos turbantes, a procura parece ser por produzir uma aparência em que a diferença é concebida em seu sentido radical.

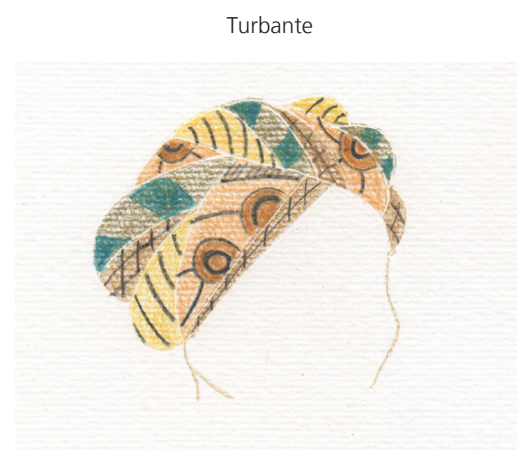

Cabelos Black

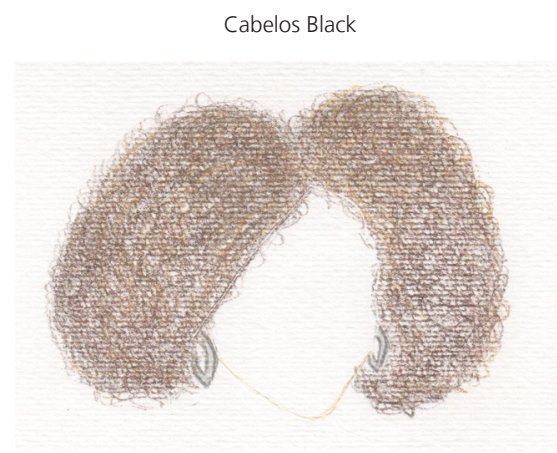

A busca por essa aparência distintiva está fortemente alicerçada na vontade de ter cabelos "naturais". É, assim, explicitamente motivada por um retorno à "naturalidade" dos cabelos negros, ao que seria a sua "essência". Deseja-se, desta forma, se ver livre dos relaxamentos e dos alisamentos, muitas vezes feitos à base de guanidina, produto químico de ação violenta, capaz de ferir o couro cabeludo: um fenômeno relativamente novo e crescente, denominado "transição capilar". Algumas moças, nessa passagem, realizam o big chop, corte bem próximo da raiz do cabelo, de modo a eliminar o mais rápido possível o cabelo tratado por "química". Outras moças preferem aguardar que o novo cabelo cresça para aos poucos apararem a porção anterior. Nesse processo, algumas recorrem às extensões de cabelos, que podem ser de cabelo humano ou sintéticas, e assim camuflar o efeito considerado indesejável de ter um cabelo parcialmente alisado ou relaxado e parcialmente crespo. ${ }^{5}$ A procura por cabelos Black retoma a ideia de uma beleza natural, dada, mesmo que estes sejam ativamente produzidos, como mostram, inclusive, os muitos vídeos tutoriais na web que ensinam como chegar ao "Black perfeito". Seja como for, o ponto dessas moças é retornar à "estrutura" original dos fios de seus cabelos. 
O turbante e os cabelos Black refazem o par dual branco/negro e desfazem a gradação produzida pelo sistema classificatório e pela nomenclatura brasileiros, ponto que um grupo de universitárias com as quais passei a conversar me permitiram refinar. O tema de nossas conversas foi motivado tanto pelos cabelos Black quanto pela discussão em torno da noção de "apropriação cultural", que busquei tomar como categoria nativa, observando seus significados para aquelas que a agenciam e os significados outros que o seu acionar engendra.

Uma fala dessas jovens universitárias - todas negras, três delas usando cabelos Black e uma delas com cabelos "ainda" alisados - me pareceu especialmente reveladora. Em resposta à minha provocação de que, ao usarem cabelos como os delas as mulheres brancas estariam manifestando apreciação por seu estilo, elas me responderam: "não é só porque acham bonitinho" que as "brancas" podem sair por aí usando penteados como os delas. Pois, seguem, levaram muito tempo para chegar a um estilo que não fosse, de suas perspectivas, um arremedo do cabelo da mulher branca.

Diferentemente de minhas amigas funk, essas jovens universitárias não querem qualquer ambiguidade em sua aparência. Muito ao contrário, querem desnudar a "pigmentocracia" brasileira e o "colorismo" que corresponde a ela não apenas para rejeitá-los, mas para igualmente denunciar a sua falácia. Querem reescrever o nosso mito da democracia racial, politizando a estética. Uma estética que já vem politizada desde seu contexto de origem, o movimento Black Power norte-americano. Pois se, com as extensões de cabelos humanos, com os cabelos ambíguos, como me disse uma cabelereira, as moças que os portam não são mais negras, nem tampouco brancas, com os cabelos Black, e também com o turbante, sua usuária fica mais "preta".

Ela é agora negra e não mais mulata, mestiça ou parda. É como se ambos, turbante e cabelos Black, desfizessem a gradação que a nomenclatura brasileira faz, tornando-as todas negras. Em certa medida podemos dizer que, assim como Judith Butler afirmou para o gênero, a raça tem também um elemento de performance, no sentido de que se pode escolher ser mais ou menos negra.

Em "Gender is burning", Butler analisa o documentário Paris is burning e, ao elaborar sobre a materialidade dos corpos junto à materialidade dos objetos, explicita seu argumento sobre a performatividade do gênero, introduzido no capítulo inicial do livro Bodies that matter (Butler 1993), de mesmo título. 
To claim that all gender is like drag, or is drag, is to suggest that "imitation" is at the heart of the heterosexual project and its gender binarisms, that drag is not a secondary imitation that presupposes a prior and original gender, but that hegemonic heterosexuality is itself a constant and repeated effort to imitate its own idealizations (Butler, 1993:125).

O filme de Jennie Livingston mostra o vai e vem entre modos mais hegemônicos e mais periféricos de ocupar o mundo que esteve na raiz do boom do house ballroom e do voguing, cena nova-iorquina formada pelos concursos de travestis e transexuais que, por meio de performances agonísticas, disputavam aquele que com maior naturalidade criaria a ilusão de ser a sua contraparte sexual. A chamada "cultura dos drag balls" pode ser traçada desde a segunda metade do século XIX, mas é a partir dos anos 1970 que a tensão racial leva à formação de "casas" [houses] que, tendo por referência as grandes "casas de moda" [fashion houses], passam a organizar concursos compostos fundamentalmente por negros. Essas casas - espécies de irmandades - foram nomeadas a partir dos grandes nomes da haute couture, como a Casa de Saint Laurent [House of Saint Laurent], compondo, como sobrenome, o nome "artístico" das performers (Lawrence 2011). Em fins dos anos 1980, o voguing e os concursos de drags chegam ao grande público, culminando na música "Vogue", da cantora pop norte-americana Madonna. ${ }^{6}$

É na articulação entre negros e brancos que esse novo boom deve ser entendido, articulação que evidencia o aspecto relacional da estética negra engendrada pela cultura do voguing, mas também as assimetrias de poder que regem as relações entre um e outro lado. Como se pode ver no documentário, a razão de ser desses concursos parece residir no mimetismo da vida dos ricos norte-americanos, que são sempre os brancos. Tornar-se mulher, para esses homens negros norte-americanos, não é tornar-se qualquer mulher, mas uma mulher branca e rica. O que move a cena drag, como retratado no documentário, é todo o devaneio realizado por sujeitos que ocupam posições precárias de trabalho, recorrendo à prostituição e aos pequenos furtos para viabilizarem a participação nessas disputas.

Se as drags recorrem a objetos materiais como roupas, sapatos, maquiagens, cabelos, gestuais e próteses corporais, entre outros recursos, para se produzirem, o mesmo vale para as normatividades sexuais que precisam cotidianamente reiterar o seu gênero em um esquema binário. Vale também, proponho, para abordarmos os diferentes sensos de self, inclusive as distintas identidades negras, ou os vários modos que uma pessoa encontra para se produzir negra. 
Ao argumentar que a raça pode ter uma dimensão performativa, não coloco em marcha uma discussão sobre a transracialização, debate acalorado suscitado pela revelação de que Rachel Dolezal, liderança de movimento negro norte-americano, era na verdade branca (Tuvel 2017). O que me parece interessante é perguntar em que medida não podemos também tomar a negritude como performativa e passível de ser performada, assim como Butler propôs em relação ao gênero. Se com os cabelos ambíguos se pode acionar a ambiguidade racial de modo agentivo, o mesmo deve valer para os cabelos Black, reivindicando etnicidade. Como afirma a atriz Ana Paula Cavalcanti,

Se não tomo sol, fico quase tão branca quanto você. Se aliso loucamente o cabelo... Só que não me interessa! É um gesto político me afirmar negra. Não vou rechaçar minhas origens apenas para me beneficiar de tudo que a branquitude oferece (Antenore 2018).

Essa recusa à invisibilidade da negritude me parece potente para adentrarmos a discussão sobre apropriação cultural. Pois se com os cabelos funk busca-se potencializar a circulação por meio de uma aparência ambígua, com os Blacks e os turbantes não se quer mais ser ambíguo, ou ser igual e diferente, mas sim procurar uma diferença absoluta em aparência e uma igualdade nos direitos. Com os cabelos Black e com os turbantes, o projeto é o de evitar, por meio da aparência, qualquer similaridade ou continuidade com modos brancos de ser e de se fazer ver. Daí a revolta e a indignação ao verem seus símbolos circulando entre os brancos, virando moda, perdendo a especificidade. Buscam-se modos especificamente negros de se autoapresentar, modos que derivam ainda de elaborações em torno de uma ancestralidade afro, como evidenciam os turbantes.

Esse temor da perda de um modo distintivamente negro de se autoapresentar aponta para o fato de que possa se desfazer o laço entre ética e estética, tão valorizado no desenvolvimento do estilo, como nos diz a afirmação de que "demoraram muito" para chegar a um cabelo que não fosse o que entendiam como um simulacro de modos brancos. O medo de que um modo próprio ao negro de se apresentar seja perdido para o "branco" ou para o "mercado", ou de que os turbantes, os Blacks (que podem ser usados como perucas) ou os dreads não causem a mesma rejeição que causariam ao serem usados por brancos parece indicar que seu significado possa ser esvaziado de sentido.

Carol Tulloch (2000), pesquisadora e curadora de moda do Victoria \& Albert Museum, em Londres, e ela mesma negra de origem caribenha, traduz o significado que o turbante adquiriu para as negras imigrantes e filhas de imigrantes na Grã-Bretanha da década de 1970. 
Through an exuberant, politically charged act of visual arbritration over the question of Blackness, Black identity and equal rights, the headtie became for Black women one of the most potent, subversive visual statements of the new global Black consciousness. The seemingly innocent function of what was just a length of cloth, qualified by its stablished profile as a humble utilitarian apparel, belied the headtie's subversive message of Black consciousness, and the acceptance of Blackness as a cultural force and finally Africa as the epicentre of Black culture (Tulloch 2000:217).

Cabelos Black e turbantes afro nos permitem pensar nessa busca pela produção de um modo distintivamente negro de se autoapresentar. De modo que o risco parece ser, ao diluir o estilo por meio de sua circulação pelo éter do mercado, o de diluir também a sua iconicidade, a sua qualidade de ícone que comunica uma especificidade. Essas jovens querem evitar a estetização de seus gostos, querem evitar que o gosto que as distingue, ao circularem por ambientes não negros, perca sua vinculação com uma ética. Por este motivo, não é apenas por acharmos "bonitinho" que podemos recorrer ao estilo, pois, para tal, é preciso também partilhar e participar de seus sentidos éticos.

\section{As extensões pop e as tecnologias de produção do self}

Foi em face de um terceiro estilo de cabelos, que chamarei de extensões pop - extensões de cabelos trançados, feitas por fio sintético em colorações como verde, azul e rosa - que notei pela primeira vez a potência de desestabilização que a estética negra pode ter sobre a paisagem da cidade. Trata-se de um estilo que se tornou icônico da chamada Geração Tombamento, que permite uma articulação com o chamado Afrofuturismo (Dery 1993) e que retém seu potencial não normativo. ${ }^{7}$ Conheci esse estilo, epitomizado por cantoras pop negras, como Carol Conka e Iza, ainda em 2014, quando circulava de carro por uma rua da Zona Sul carioca, área privilegiada do Rio de Janeiro.

Avistei Blue, como a chamarei, quando dirigia pelas imediações da Gávea, bairro da Zona Sul carioca. Ela caminhava por uma rua do bairro, um tanto erma, margeada por um canal que liga a Gávea ao Leblon. Seus cabelos azuis, trançados e longuíssimos capturaram o meu olhar. Cabelos que chegavam ao meio de suas coxas e compunham um corpo todo ele não hegemônico, tanto por sua cor quanto por sua forma, que escapava ao padrão das pequenas modelagens. Cabelos que à época eram incomuns. Não resisti, parei o carro e conversei um pouco com a jovem, aproveitando 
para pedir autorização para fotografá-la. Negra, Blue era estudante do Curso de Design da Pontifícia Universidade Católica do Rio de Janeiro, onde era provavelmente bolsista, como é a grande maioria dos alunos negros desta universidade, localizada naquela que é considerada por excelência área privilegiada da cidade. Não consegui saber mais de Blue, que vinha da PUC em direção ao ponto de ônibus no qual pegaria sua condução. Volto a ela hoje, pois, diferentemente de minhas amigas funk - e penso que foi por isso que ela tanto me interessou - Blue evidencia muito claramente, por meio de seus cabelos, a artefatualidade da sua beleza e da sua aparência.

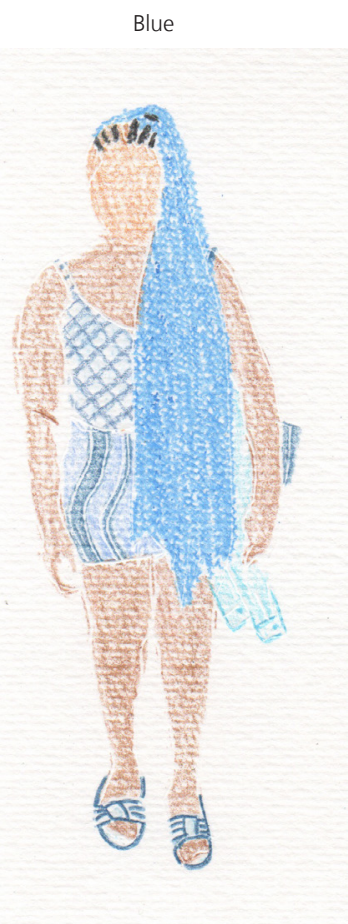

Cabelos que assumem a sua condição de adorno, que parecem colocados como um acessório, cuja artificialidade não se busca burlar, como os cabelos femininos funk desejam. Se foi preciso de fato muito tempo para eu notar as extensões de cabelos junto ao funk, com Blue isto não ocorreu. Ela toma seus cabelos evidentemente como uma tecnologia através da qual ela se produz e se dá a ver. Cabelos azuis que combinavam com todo o seu conjunto indumentário naquela tarde: short em blue jeans listrado de branco e de dois tons de azul, sandálias da marca Adidas em azul marinho e detalhes brancos, e a também azul jaqueta jeans que ela carregava sobre sua bolsa. 
Blue parecia querer nos convencer de que a aparência não tem nada de superficial, que com ela as potências do self são trazidas à tona em um processo que depende do oscilar de perspectivas entre o que olha e o que é olhado (Strathern 2013). Não à toa, é no espaço urbano que investimos mais intensamente na nossa aparência, no vai e vem de olhares e perspectivas envolvidos no momento da performance (Mizrahi 2018a). Com as extensões pop, conhecemos mulheres negras que deliberadamente expõem a artefatualidade de sua beleza. Evidenciam a artefatualidade da beleza e da aparência através de seus cabelos notadamente sintéticos, que se afinam com outros adornos, como óculos de sol, unhas, tatuagens, além de roupas, colares, brincos, anéis, pulseiras, sapatos, bolsas e outros acessórios, na assemblage da pessoa.

Blue traz à tona a artefatualidade da beleza e do corpo. Com suas extensões pop, simulacros evidentes de cabelos humanos, a naturalidade escamoteada pelos cabelos ambíguos, que elidem a sua artefatualidade, e explicitamente reivindicada pelos cabelos Black no próprio desenvolvimento do estilo - não é mais uma questão.

As extensões pop, ao evidenciarem o seu aspecto de feito por meio da artificialidade de sua aparência, não buscam uma "conciliação com a ordem hegemônica", para recorrermos à provocação feita por Kobena Mercer (2000). Especialista em arte contemporânea do Atlântico negro, o historiador parte da própria designação "afro", sugestiva de um elo entre a África e a natureza, que subentenderia uma oposição a qualquer tipo de artifício técnico, para criticar duramente a lógica que equaciona a "naturalidade" dos cabelos com uma identidade negra considerada autêntica. Nesse pendor, todo elemento de artificialidade seria imitativo de ideais estéticos brancos e eurocêntricos. Por outro lado, argumenta o autor, a artefatualidade é na verdade um modo mais propriamente africano de levar a efeito a produção estética, um tipo de sensibilidade que incorpora as práticas de embelezamento à vida cotidiana e que contrasta com uma concepção da vida social definida pela separação em domínios especializados. Desta perspectiva, os cabelos "naturais", fossem na forma de cabelos afro, ou dos dreadlocks, só poderiam corresponder a uma África imaginada. Em sociedades africanas, tais estilos jamais significariam "africanidade", mas, ao contrário, uma identificação com o Primeiro Mundo (Mercer 2000:116-120). ${ }^{8}$

A artefatualidade que acompanhamos na composição das diferentes mulheres deste texto - por meio de extensões sintéticas e coloridas, dos processos de colocar e retirar cabelos humanos, dos relaxamentos e alisamentos, da transição capilar - aponta para uma onipresença da tecnologia, o que nos obriga a repensar a definição de corpo como entidade biológica 
e circunscrita de modo amplo, inclusive em contextos moderno-ocidentais (Moore 1996). Isto permite reforçar o argumento de que não é possível fazer-nos humanos sem nos imbricarmos e sem reconhecermos nossa necessária dependência de instâncias não humanas, sejam objetos tecnológicos, bactérias de laboratório, espíritos, roupas, cabelos ou aparelhos auditivos. Nos termos de Bruno Latour (2005), somos sempre um actant.

Mas se a onipresença da tecnologia permite enfatizar o fato de que a prótese é não extraordinária, mas estabelece a sua continuidade com os objetos corporais prosaicos que compõem as estratégias de autoapresentação, esse sermos todos ciborgues adquire uma conotação outra quando se colocam em questão as relações raciais e ainda as clivagens de classe e as assimetrias de gênero. Pois o que as jovens negras que vimos aqui dizem por meio de seus cabelos - umas de modo mais explícito, outras de modo mais velado parece ser aquilo que moveu Donna Haraway (2009) em sua conceituação do ciborgue: uma assemblage que resulta de uma politização da estética. Por meio da incorporação de objetos produz-se um self que resulta de sua busca por burlar a natureza do corpo e as reações a ela.

As extensões pop aglutinam muitos dos tensionamentos apontados ao longo deste texto. Sugiro que elas podem ser tomadas como a atualização contemporânea dos turbantes afro. São simultaneamente tradicionais, na medida em que permitem reivindicar etnicidade, e fashion, em seus coloridos e composições. Materializam uma identidade negra, ao mesmo tempo em que propõem uma discussão sobre ela, permitindo pensá-la mais propriamente como uma instabilidade. São assim "tradicionais" como seriam as manifestações próprias ao Atlântico negro, espaço de trânsitos e deslocamentos. Nesse sentido, propõe Paul Gilroy,

o termo "tradição" não está agora sendo usado para identificar um passado perdido nem para nomear uma cultura de compensação que restabeleceria acesso a ele. Ele não se encontra em oposição à modernidade, nem deve conjurar imagens íntegras da África que possam ser contrastadas com o poder corrosivo, afásico, da história pós-escravidão das Américas e do Caribe ampliado (Gilroy 2001:371).

As extensões pops, suas colorações e texturas "artificiais" contêm a iminência de sua apropriação e apontam para uma identidade Black, propondo uma discussão sobre a noção de "apropriação cultural". Sua artificialidade traz para o jogo a mediação exercida pelo mercado e o fato de que se trata, sempre, de bens e serviços amplamente disponibilizados ao público geral, e passíveis, portanto, de serem tomados. São coisas tornadas símbolos étnicos a partir de usos, produções e estéticas contemporâneos que são, neste sentido, diferentes da remissão mais imediata a uma ancestralidade afro, como 
fazem os turbantes, sem, contudo, negá-la. São elaborações miméticas sobre a ancestralidade africana, sobre os cabelos trançados tradicionais, convertidas em signos de afirmação de identidades étnicas por meio de processos apropriadores que não denotam a ideia de expropriação contida na noção de apropriação cultural. Ao serem tomadas por ativistas de movimentos negros, as extensões pop forçam o reconhecimento das potências que a articulação entre estética, consumo e política oferece. É através do consumo que se produz uma estética tornada discursividade política.

\section{Considerações finais}

Iniciei este artigo perguntando em que medida podemos falar em uma estética negra? Mais propriamente, me perguntei o que haveria de distintivo em estéticas adjetivadas como negras para que as qualificássemos como tais. Esta particularidade, como os diferentes estilos aqui explorados nos mostraram, não reside nem no corpo, nem no gosto, mas se traduz em um "jeito", como disse Célia. A estética não é uma coisa que nos permite singularizar culturas, povos ou estilos, mas uma agência, uma potência transformativa, produtora de efeitos no mundo social, como podemos propor a partir de Gell (1998). Um processo de produção da forma no qual o corpo surge profundamente engajado, como defendeu Buck-Morss (2012).

Foi de acordo com esta perspectiva que busquei delinear a ideia de estética negra a partir de sua relacionalidade e dissidência. Uma relacionalidade exercida por meio da dissidência. É na busca pela diferença, na busca por produzi-la e retê-la que essa relacionalidade é vivida, concretizada, performada, seja a partir da circulação pelo espaço público, colocando em relação, de um lado, gostos hegemônicos e oficiais e, de outro, aqueles produzidos e apreendidos como diferentes, seja a partir de relações de disputa intragênero pautadas por relações raciais.

Essa relacionalidade está contida nos três estilos aqui delineados. No primeiro deles, os cabelos ambíguos, vemos um estilo que se mimetiza cabelos de brancos, o faz de modo a buscar um caminho outro. Um estilo que contribui ainda para a conceituação de uma estética relacional dissidente. Ao acompanhar a produção da pessoa feminina funk, via a produção de beleza, obtive pistas para atingir a centralidade que as relações entre mulheres negras e brancas, nem sempre harmônicas, adquirem na produção da beleza negra. Essa centralidade retornou quando delineei o segundo estilo de cabelos, o Black, ao qual aliei ainda os turbantes afro. Cabelos Black, ou afro, e turbantes levaram a uma discussão sobre apropriação cultural, 
entendendo-a como recusa à estetização de gostos e à despolitização da estética. Junto aos Blacks e aos turbantes, pude ainda acessar a dimensão performativa da raça; a possibilidade de acionar a raça como modo de se colocar no mundo. Por fim, cheguei às extensões pop, que aglutinam uma série de tensionamentos que nortearam este artigo, o que me levou a propor que as tomemos como os novos turbantes. São elaborações que mimetizam modos tradicionais e ancestrais africanos a partir de processos apropriativos, sem negar os poderes da artefatualidade e da modernidade.

Com as extensões pop, vemos mais claramente o self se produzir ao produzir seu corpo, acionando tanto a materialidade dos corpos, no sentido de Butler (1993), como a materialidade dos objetos, no sentido de Miller (2005). É nessa confluência e por meio do consumo que estetizamos nossos corpos e politizamos nossas aparências. Aqui, a noção de performatividade de gênero é especialmente relevante, pois se o gênero não está nunca dado, mas precisa ser permanentemente reiterado através de atos de performance, esses mesmos atos necessitam recorrer às coisas para serem concretizados e terem seus efeitos garantidos. É, portanto, em um processo de desalienação dos bens de consumo - o meio pelo qual nos apropriamos das coisas - que podemos reiterar não apenas o nosso gênero, mas o modo como nos entendemos e nos posicionamos no mundo - os nossos diferentes sensos de self.

Ao elaborar sobre a centralidade da aparência nas interações sociais desenroladas nos espaços públicos da cidade, fui guiada pela vontade de complexificar a ideia de que a beleza é "mera" aparência, de que os significados que a superfície do corpo comunica são eles mesmos superficiais, contribuindo ainda para notarmos como esse corpo artefatual produz um desmantelar das distinções entre sujeito e objeto. Vimos o self se produzir ao produzir o corpo, trazendo uma concepção de beleza enquanto feita e muito distante de uma noção dadivosa da aparência. Uma potência de transformabilidade da pessoa visível não apenas na fluidez com que cabelos são colocados e retirados, mas também em unhas, dentes, seios, nádegas e outras próteses, como lentes de contato coloridas. Podemos assim pensar os cabelos, as perucas, a roupa e a decoração do corpo como coberturas e como superfícies reais e significativas, da mesma forma que as tatuagens polinésias exploradas por Gell (1993). Agem ativamente em seu posicionamento no mundo.

Recebido em: 12 de fevereiro de 2019

Aprovado em: 23 de julho de 2019 
Professora do Departamento de Educação da Pontifícia Universidade Católica do Rio de Janeiro (PUC-Rio) e coordenadora do EstetiPop (Laboratório de Estéticas, Cultura Pop/Popular e Antropologia). Doutora em Antropologia Cultural pela Universidade Federal do Rio de Janeiro (UFRJ). Sua tese de doutorado, intitulada A estética funk carioca: criação e conectividade em Mr. Catra, recebeu o primeiro lugar do Prêmio IPP Rio Maurício de Almeida Abreu e foi publicada pela Editora 7Letras. É autora ainda de Figurino funk: roupa, corpo e dança em um baile carioca, pela mesma editora, e de diversos artigos em periódicos e coletâneas nacionais e estrangeiras. Seus interesses de pesquisa incluem estética, criatividade, corporalidade, relações raciais, materialidades, visualidade, sonoridades, consumo, redes de conexões, cultura pop/popular, juventude, escola.

ORCID https://orcid.org/0000-0002-0661-2273

E-mail: mylenemizrahi@gmail.com

\section{Notas}

${ }^{*}$ As elaborações que trago neste artigo foram gestadas em diferentes apresentações em eventos acadêmicos e conversas com colegas. Sendo elas de minha inteira responsabilidade, gostaria de agradecer às sugestões e aos comentários de Felipe Sussekind, Gabriel Bannagia, Guilherme Sá, Isadora Lins França, João Bittencourt, Laura Graziela Gomes, Maria Elvira Diaz Benitez, Olívia Maria Gomes da Cunha, Patricia Reinheimer, Roberto DaMatta, Sonia Giacomini, Scott Head. Agradeço igualmente aos sujeitos presentes nessa minha narrativa, cujas formulações foram fundamentais para que eu fizesse as minhas próprias. Seus nomes foram alterados para proteger suas identidades e atender às demandas de conformidade ética. Agradeço ainda à editoria e à parecerista de Mana que certamente contribuíram para tornar este texto mais coeso e inteligível, além de torná-lo mais rico. Por fim, noto que todos os desenhos que ilustram este artigo são de minha autoria.

1 O trabalho de campo se realizou em dois períodos de 18 meses, transcorridos entre 2005 e 2008, além de incursões a campo posteriores. O primeiro período correspondeu à pesquisa de mestrado, conduzida junto a um grupo de jovens frequentadores de um baile funk, aos quais acompanhei também em seus locais de trabalho e moradia, em suas saídas para compras, em suas visitas ao cabeleireiro (Mizrahi 2019). O segundo período correspondeu à pesquisa de doutorado, conduzida junto à rede de relações do cantor Mr. Catra e concretizada nos deslocamentos pela cidade para cumprir sua agenda de shows, no estúdio de gravação do coletivo Sagrada Família, e nas atividades domésticas e familiares (Mizrahi 2014).

2 Outra fonte faz entender que Walker é a primeira mulher, branca ou negra, a entrar no rol dos milionários estadunidenses (Shen 2016). 
3 Explorei com mais detalhes, inclusive por meio de descrição etnográfica, o referido estilo de cabelos em duas outras ocasiões (Mizrahi 2012, 2015).

4 Note-se que Leach faz raciocínio análogo em Sistemas políticos da Alta Birmânia (Leach 1996), quando afirma que não lhe interessa saber o porquê de determinados elementos materiais - a cabeça coberta por turbante ou a aliança no dedo anelar - serem eleitos para simbolizarem, por exemplo, o estado marital.

5 Nos últimos anos diferentes pesquisas vêm mapeando os processos de transição capilar bem como outros que fazem do cabelo entrada potente para tomada de consciência de uma identidade negra. Ver, entre outros, Bouzon (2010), Quintão (2013), Cruz (2013), Albuquerque (2015), C. F. A. Gomes (2017), L. P. Gomes (2017), Oliveira (2017), Santos (2017).

6 Vogue, de Madonna. Disponível em https://www.youtube.com/watch?v=GuJQSAiODqI. Acesso em 28/11/2018.

7 Geração Tombamento é o nome dado a uma geração de jovens negros que fizeram da autoapresentação estratégia de visibilização de suas identidades negras por meio de um estilo definido a partir da incorporação de bens de consumo indumentários e de moda. Para trabalhos sobre o tema, ver Almeida (2017), Leite e Souza (2017), Santos (2017), Barros (2018).

8 Vale notar que o argumento no cerne da crítica de Mercer, centrada na valorização do artifício e da agência das mãos humanas em culturas africanas, faz todo o sentido e foi feito, por outros caminhos, por Bruno Latour (2002) em sua discussão sobre o fetiche africano. 


\section{Referências bibliográficas}

ALBUQUERQUE, Sofia Oliveira Firmo de. 2015. Cacheadas: o movimento de retorno e valorização dos cabelos cacheados e crespos. Monografia, Universidade Federal Fluminense.

ALMEIDA, Adriele Regine dos Santos. 2017. "'Mamacita fala, vagabundo senta!: empoderamento feminino e 'Geração Tombamento'". Transformações, conexões e deslocamentos. Anais do $11^{\circ}$ Seminário Internacional Fazendo Gênero \& 13th Women's Worlds Congress.

ANTENORE, Armando. 2018. "A revanche da babá: uma atriz em busca da própria cura. Piauí, CCLX. Disponível em http://piaui.folha.uol.com.br/ materia/revanche-da-baba/. Acesso em 04/11/2018.

BALDWIN, James. 2017. "O estranho no vilarejo. Serrote, XXVI:114-131.

BARROS, Maria Beatriz dos Santos. 2018. "Causando um tombamento: Karol Conká e a negritude". Anais da III Jornada GEMIninS, UFSCar.

BENJAMIN, Walter. 2012. "A obra de arte na era de sua reprodutibilidade técnica". In: T. Capistrano (org.), Benjamin e a obra de arte: técnica, imagem, percepção. Rio de Janeiro: Contraponto.

BOURDIEU, Pierre. 1984. Distinction: a social critique of the judgment of taste. London: Routledge and Kegan Paul.

BOURRIAUD, Nicolas. 2002. Relational aesthetics. Dijon: Les presses du reel. BOUZÓN, Patricia. 2010. Construindo identidades: um estudo etnográfico sobre manipulação da aparência em salóes de beleza na cidade do Rio de Janeiro. Tese de Doutorado, Universidade Federal do Rio de Janeiro.
BUTLER, Judith. 1993. Bodies that matter: on the discursive limits of sex. London: Routledge.

BUCK-MORSS, Susan. 2012. "Estética e anestética: uma reconsideração de A obra de arte de Walter Benjamin". In: T. Capistrano (org.), Benjamin e a obra de arte: técnica, imagem, percepção. Rio de Janeiro: Contraponto.

CRUZ, Cíntia Tamara Pinto da. 2013. Os cabelos mágicos: identidade e consumo de mulheres afrodescendentes no Instituto Beleza Natural. Dissertação de Mestrado, Universidade Federal do Recôncavo da Bahia.

DERY, Mark. 1993. Flame Wars: The Discourse of Cyberculture. Durham: Duke University Press.

EGLASH, Ron. 2005. African fractals: modern computing and indigenous design. New Brunswick, New Jersey and London: Rutgers University Press.

GATES JR., Henry Louis. 1994. "In the kitchen". The New Yorker, 18 de abril.

GARBER, Marjorie \& VICKERS, Nancy J. (orgs.). 2003. The medusa reader. New York: Routledge.

GELL, Alfred. 1992. "The technology of enchantment and the enchantment of technology". J. Coote \& A. Shelton (orgs.), Anthropology, Art and Aesthetics. Oxford: Claredon Press. . 1993. Wrapping in images: tattooing in Polynesia. Oxford: Clarendon Press.

. 1998. Art and agency, an anthropological theory. Oxford: Clarendon Press.

GILROY, Paul. 2001. O Atlântico negro: modernidade e dupla consciência. Rio de Janeiro: Universidade Candido Mendes, Centro de Estudos Afro-Asiáticos. 
GILMAN, Sander. 1999. Making the body beautiful: a cultural history of aesthetic surgery. Princeton, Oxford: Princeton University Press.

GOMES, Nilma Lino. 2006. Sem perder a raiz: corpo e cabelo como símbolos da identidade negra. Belo Horizonte: Aute $\square$ ntica.

GOMES, Claudia Ferreira Alexandre. 2017. A identidade negra e o consumo de cosméticos afro. Dissertação de Mestrado, Universidade Federal Rural de Pernambuco.

GOMES, Larisse Pontes. 2017. "'Posso tocar no seu cabelo?', entre o liso e o crespo: transição capilar, uma (re) construção identitária". Dissertação de Mestrado, Universidade Federal de Santa Catarina.

HARAWAY, Donna. 2009. "Manifesto ciborgue: ciência, tecnologia e feminismo-socialista no final do século XX". In: T. Tadeu (org.), Antropologia do ciborgue: as vertigens do pós-humano. 2. ed. Belo Horizonte: Autêntica Editora. pp. 33-118.

HOLBRAAD, Martin. 2007. "The power of powder: multiplicity and motion in the divinatory cosmology of Cuban Ifá (or mana, again)". In: A. M. Henare; M. Holbraad \& S. WAstell (orgs.), Thinking through things: theorizing artefacts ethnographically. London, New York: Routledge. pp. 189-225.

INGOLD, Tim. 1994. "Aesthetics is a cross-cultural category". In: (org.), Key Debates in Anthropology. London: Routledge. pp. 249-293.

LAGROU, Els. 2018. "Anaconda-becoming: Huni Kuin image-songs, an Amerindian relational aesthetics". Horizontes Antropológicos, XXIV (51):17-49.

LATOUR, Bruno. 2002. Reflexão sobre o culto moderno dos deuses fe(i) tiches. Bauru: EDUSC. 2005. Reassembling the Social. Oxford: Oxford University Press.
LAWRENCE, Tim. 2011. "Listen, and you will hear all the houses that walked there before: a history of drag balls, houses and the culture of voguing. In: S. Baker (org.), Voguing and the house ballroom scene of New York City, 1989-92. pp. 3-10.

LEACH, Edmund. 1983. "Cabelo mágico". In: R. DaMatta, Leach. São Paulo: Ática. pp. 139-169. 1996. Sistemas políticos da Alta Birmânia. São Paulo: Editora da Universidade de São Paulo.

LEITE, Nara de Cervino Teixeira \& SOUZA, Josenilde Silva. 2017. "Geração Afrotombamento baiana: a estética negra como meio difusor de empoderamento". Anais do $13^{\circ}$ Colóquio de Moda.

LODY, Raul. 2004. Cabelos de axé: identidade e resistência. Rio de Janeiro: Ed. Senac Nacional.

MERCER, Kobena. 2000. "Black hair/ style politics". In: O. Kwesi, Black British culture and society. London: Routledge. pp. 111-121.

MILLER, Daniel. 2005. "Materiality: an introduction". In: , Materiality. Durham, London: Duke University Press. pp. 1-50.

MIZRAHI, Mylene. 2012. "Cabelos como extensões: relações protéticas, materialidade e agência na estética funk carioca". Textos Escolhidos de Cultura e Arte Populares, IX (2):137-157. 2014. A estética funk carioca: criação e conectividade em Mr. Catra. Rio de Janeiro: 7Letras.

. 2015. "Cabelos ambíguos: beleza, poder de compra e 'raça' no Brasil urbano". Revista Brasileira de Ciências Sociais, XXX (89):31-45.

. 2018a. "O Rio de Janeiro é uma terra de homens vaidosos: mulheres, masculinidade e dinheiro junto ao funk carioca". Cadernos Pagu, LII. 
.2018b. "Mr. Catra e sua vontade pela margem: Judaísmo, negros e brancos na formação de um artista não erudito". Religião e Sociedade, Rio de Janeiro, XXXVIII (3):19-40. 2019. Figurino funk: roupa, corpo e dança em um baile carioca. Rio de Janeiro: 7Letras.

MOORE, Henrietta. 1996. "The changing nature of anthropological knowledge: an introduction". In: _, The Future of Anthropological Knowledge. London: Routledge Press. pp. 1-15.

OLIVEIRA, Paula Beatriz de Carvalho. 2017. Ressignificações em torno de cabelos crespos e cacheados: uma análise sobre performances corporais nas favelas Chapéu Mangueira e Babilônia. Dissertação de Mestrado, Universidade Federal Fluminense.

QUINTÃO, Adriana Maria Penna. 2013. O que ela tem na cabeça?: Um estudo sobre o cabelo como performance identitária. Dissertação de Mestrado, Universidade Federal Fluminense.

RANCIÈRE, Jaques. 2005. A partilha do sensível. São Paulo: Editora 34.

SAHLINS, Marshall. 2003. Cultura e razão prática. Rio de Janeiro: Jorge Zahar Editor.

SANTOS, Ana Paula Medeiros Teixeira dos. 2017. Tranças, turbantes e empoderamento de mulheres negras: artefatos de moda como tecnologias de gênero e raça no evento Afro Chic (Curitiba-PR). Dissertação de Mestrado, Universidade Tecnológica Federal do Paraná.
SHEN, Ann. 2016. Bad girls throughout history. San Francisco: Chronicle Books.

STEPHENS, Michelle Ann. 2014. Skin acts: race, psychoanalysis, and the Black male performer. Durham and London: Duke University Press.

STRATHERN, Marylin. 2004. Partial connections. 2. ed. Lanham: Altamira Press.

2013. Learning to see in Melanesia. Lectures given in the Department of Social Anthropology, University of Cambridge, 1993-2008, HAU Marterclass Series, v. 2.

TARLO, Emma. 2016. Entanglement: the secret lives of hair. London: OneWorld Publications.

TULLOCH, Carol. 2000. "That little magic touch". In: O. Kwesi, Black British culture and society. London: Routledge. pp. 207-219.

TUVEL, Rebecca. 2017. "In Defense of Transracialism". Hypatia, XXXII (2) :263-278

VIVEROS VIGOYA, Mara. 2018. As cores da masculinidade: experiências interseccionais e práticas de poder na Nossa América. Rio de janeiro: Papéis Selvagens.

\section{Filmografia}

LIVINGSTON, Jennie (direção e texto). 1990. Paris is burning. Filme-documentário, 76'. Estados Unidos. 


\section{AS POLÍTICAS DOS CABELOS \\ NEGROS, ENTRE MULHERES: \\ ESTÉTICA, RELACIONALIDADE E DISSIDÊNCIA NO RIO DE JANEIRO}

\section{Resumo}

O artigo é norteado pela pergunta relativa ao que haveria de distintivo em estéticas adjetivadas como negras. Em busca de uma resposta, analiso três estilos de cabelos femininos: o produzido por extensões de cabelo humano; os cabelos Black; os produzidos por extensões de cabelo sintético. Argumento a favor de uma estética relacional dissidente, que se engendra a partir de relações nem sempre harmônicas entre negras e brancas e que se constitui por sua fuga da norma - o gosto hegemônico branco - ao mesmo tempo em que elabora esteticamente sobre esta mesma norma. Junto a uma discussão englobante sobre a estética e seus poderes, analiso a dimensão performativa da raça, a noção de apropriação cultural, as noções de beleza feita e de corpo artefatual, propondo que em sociedades modernas ocidentais é por meio da apropriação das coisas ofertadas como bens e serviços de consumo que estetizamos nossos corpos e produzimos discursividades políticas.

Palavras-chave: Relações raciais; Corpo; Estética; Materialidades; Consumo.

\section{LAS POLÍTICAS DEL PELO NEGRO: ESTÉTICA, RELACIONALIDAD Y DISIDENCIA EN RÍO DE JANEIRO}

\section{Resumen}

Este artículo pregunta en que medida podemos calificar determinadas estéticas como negras. En busca de una respuesta, analizo tres estilos de cabellos femeninos: el producido por extensiones de pelo humano; el cabello afro; el producido por extensiones de pelo sintético. Argumento a favor de una estética relacional disidente que se engendra a partir de relaciones no siempre armónicas entre negras y blancas y que se constituye por su distanciamiento de la norma - el gusto hegemónico blanco - al mismo tiempo en que elaborando esteticamente sobre esta misma norma. Junto a una discusión que abarca la estética y sus poderes, analizo la dimensión performativa de la raza, la noción de apropiación cultural, las nociones de belleza que vienen del cuerpo artefactual, proponiendo que en sociedades modernas occidentales la estetización de nuestros cuerpos produce discursividades políticas junto a la apropiación de los bienes y servicios de consumo.

Palavras clave: Relaciones raciales; Cuerpo; Estética; Materialidades; Consumo. 
THE POLITICS OF BLACK HAIR, AMONG WOMEN: AESTHETICS, RELATIONALITY AND DISSENT IN RIO DE JANEIRO

\author{
Abstract \\ The article discusses what might be \\ distinctive in so-called Black aesthetics. \\ In search of an answer, I analyse three \\ styles of female hair: hairdos made \\ with human hair extensions; the Afro \\ hair; hairdos made with synthetic \\ hair extensions. I argue in favour of a \\ dissident relational aesthetics that is \\ generated from not always harmonic \\ relations between Black and white
}

women and which is constituted by its refusal to conform to the norm of white hegemonic taste, while also elaborating aesthetically on this same norm. Along with an encompassing discussion on aesthetics and their powers, I also analyse the performative dimension of race and the notions of cultural appropriation and the artefactual body. I propose that in modern Western societies we aestheticize our bodies and produce political discursiveness by the appropriation of consumer goods and services.

Key words: Racial relations; Body; Aesthetics; Materiality; Consumption. 